direction. The main course was from west to east. He also saw it at Pernambuco, at Rio Janeiro, and in the Southern States of America, but nowhere so abundant as on the Amazons. The Urania is scarcely a butterfly; but between the day and night butterflies, something between a skipper and a hawk moth. By Latreille they were called Hespero-Sphyngidæ. The larvæ and pupæ are supposed not to have been adequately examined. The Liverpool naturalist could not identify them, and as yet they have not been able to find them at Panama. In Central Ameri a the Urania is found as far north as Guatemala. Mr. Darwin observed a butterfly of similar habits, the Pipilio feronio, which frequents orange groves.

\section{THE ROYAL SOCIETY'S LIST FOR I87I}

$T$ TE following fifteen have been selected by the Council 1 of the Royal Society out of the fifty candidates, and recommended to the Fellows for election:-William Henry Besant, M.A., Mathematical Lecturer at St. John's College; Senior Wrangler and First Smith's Prizeman in 1850, Moderator in 1856 , Examiner in the University of London from 1860 to I 865 ; author of Treatises on " $\mathrm{Hy}$ dromechanics and the Theory of Sound," 2nd ed. 1867; "Elementary Hydrostatics," and ed. 1867 ; "Geometrical Conic Sections," 1869; "Roulettes and Glissettes," I 870. William Budd, M.D. (Edin.), physician, author of various medical papers, especially relating to contagious diseases. George W. Callender, F.R.C.S., lecturer on Anatomy at St. Bartholomew's Hospital School, and Assistant Surgeon to Bartholomew's Hospital ; author of Anatomical papers. William Carruthers, F. L.S., F.G.S., keeper of the Botanical Department, British Museum ; author of "Fossil Cycadean Stems from the Secondary Rocks of Britain "" "On the Structure and Affinities of Sigillaria and Allied Genera ;" "The Cryptogamic Forests of the Coal Period;" "On the Structure of the Stems of the Arborescent Lycopodiaceæ of the Coal-measures;" "Revision of the British Graptolites," \&c. Robert Etheridge, F.R.S.E., F.G.S., Palæontologist to H.M. Geological Survey of Great Britain; Demonstrator on Palæontology, Royal School of Mines; author of numerous geological papers. Frederick Guthrie, B.A., F.R.S.E. F.C.S., Professor of Physics in the Royal School of Mines; author of various papers on Chemistry and Physics. Captain fohn Herschel, R.E., of the Great Trigonometrical Survey of India. Captain Alexander Moncrieff, Militia Artillery, C.E., inventor of the Moncrieff gun-carriage, and author of the Moncrieff system of defence. Richard Quain, M.D. (Lond.), Fellow and late Censor of the Royal College of Physicians; author of a paper "On Fatty Degeneration of the Heart," which has exerted a marked influence on certain branches of Pathological Science; and of numerous communications published in the Transactions of the Pathological Society, of which Society he was President (1869-70). Carl Schorlemmer, Senior Assistant in Owens College Laboratory, Manchester ; author of a series of papers on the Constitution of the Paraffins, chiefly published in the Proceedings of the Society since 1862. Edward Thomas, Treas. R.A.S.; author of numerous papers on Indian Coins and Gems. Edward Burnet Tylor, author of "Researches into the Early History of Mankind ;" "Primitive Culture ;" and various memoirs on Savages and their Customs. Cromwell Fleetwood Varley, Civil and Telegraphic Engineer, M.I.C.E. ; Consulting Electrician to the Electric and International Telegraph Company, the Atlantic Telegraph Company, la Société du Cable Transatlantique Français; author of many inventions in connection with the Electric Telegraph. Viscount Walden, President of the Zoological Society of London; author of various papers on Ornithology. Fohn Wood, F.R.C.S., Examiner in Anatomy at the University of London; author of a number of anatomical papers published in the Phil. Trans.

\section{ON COLOUR VISION *}

$A$ LL vision is colour vision, for it is only by observing differences of colour that we distinguish the forms of objects. I include differences of brightness or shade among differences of colour.

It was in the Royal Institution, about the beginning of this century, that Thomas Young made the first distinct announcement of that doctrine of the vision of colours which I propose to illustrate. We may state it thus :-We are capable of feeling three different colour-sensations. Light of different kinds excites these sensations in different proportions, and it is by the different combinations of these three primary sensations that all the varieties of visible colour are produced. In this statement there is one word on which we must fix our attention. That word is, Sensation. It seems almost a truism to say that colour is a sensation; and yet Young, by honestly recognising this elementary truth, established the first consistent theory of colour. So far as $I$ know, Thomas Young was the first who, starting from the well-known fact that there are three primary colours, sought for the explanation of this fact, not in the nature of light, but in the constitution of man. Even of those who have written on colour since the time of Young, some have supposed that they ought to study the properties of pigments, and others that they ought to analyse the rays of light. They have sought for a knowledge of colour by examining something in external nature - something out of ourselves.

Now, if the sensation which we call colour has any laws, it must be something in our own nature which determines the form of these laws; and I need not tell you that the only evidence we can obtain respecting ourselves is derived from consciousness.

The science of colour must therefore be regarded as essentially a mental science. It differs from the greater part of what is called mental science in the large use which it makes of the physical sciences, and in particular of optics and anatomy. But it gives evidence that it is a mental science by the numerous illustrations which it furnishes of various operations of the mind.

In this place we always feel on firmer ground when we are dealing with physical science. I shall therefore begin by showing how we apply the discoveries of Newton to the manipulation of light, so as to give you an opportunity of fecling for yourselves the different sensations of colour.

Before the time of Newton, white light was supposed to be of all known things the purest. When light appears coloured, it was supposed to have become contaminated by coming into contact with gross bodies. We may still think white light the emblem of purity, though Newton has taught us that its purity does not consist in simplicity.

We now form the prismatic spectrum on the screen. These are the simple colours of which white light is always made up. We can distinguish a great many hues in passing from the one end to the other; but it is when we employ powerful spectroscopes, or avail ourselves of the labours of those who have mapped out the spectrum, that we become aware of the immense multitude of different kinds of light, every one of which has been the object of special study. Every increase of the power of our instruments increases in the same proportion the number of lines visible in the spectrum.

All light, as Newton proved, is composed of these rays taken in different proportions. Objects which we call coloured when illuminated by white light, make a selection of these rays, and our eyes receive from them only a part of the light which falls on them. But if they receive only the pure rays of a single colour of the spectrum, they can appear only of that colour. If I place a disc containing alternate quadrants of red and green pap̃er in the red rays, it appears all red, but the red quadrants brightest. If I place it in the green rays both papers appear green, but the red paper is now the darkest. This, then, is the optical explanation of the colours of bodies when illuminated with white light They separate the white light into its component parts, absorbing some and scattering others.

Here are two transparent solutions. One appears yellow, it contains bichromate of potash; the other appears blue, it con. tains sulphate of copper. If I transmit the light of the electric lamp through the two solutions at once, the spot on the screen appears green. By means of the spectrum we shall be able to explain this. The yellow solution cuts off the blue end of the spectrum, leaving only the red, orange, yellow, and green. The blue solution cuts off the red end, leaving only the green, blue, and violet. The only light which can get through both is the * Lecture delivered before the Royal Institution, March.24th. 